\title{
Sustainable Economic Growth: a Perspective for Macedonia
}

\author{
Sevil Rexhepi \\ Department of Public Administration and Political Sciences \\ South East European University, Tetovo, Macedonia \\ e-mail: s.rexhepi@seeu.edu.mk
}

Cite as: Rexhepi, S., Sustainable Economic Growth: a Perspective for Macedonia, J. sustain. dev. energy water environ. syst., 1(3), pp 272-280, 2013, DOI: http://dx.doi.org/10.13044/i.sdewes.2013.01.0020

\begin{abstract}
Retrospective analysis shows that since 1990's, ex-socialist economies were in transition. This process was multidimensional and had deep roots. In most transition economies, output (GDP) is determined by the availability of labour, capital and their productivity (TFP). Hence, these indicators are not generating the business cycles, which is typical for market economies in the long-term. At this point, it is vital to understand the reasons of low-level of capital accumulation in transition economies in order to find opportunities to make better use of physical, human and social capital. Furthermore, it is observed that in these economies, institutions needed to be re-established or the rules of the game needed to be changed to regulate incentive structures that will lead to growth. The main objective of this research is to identify the peculiarity of economic growth in Macedonia and to examine if achieving smart growth in long-term is possible; which is supported by fundamental notions of sustainable development.
\end{abstract}

\section{KEYWORDS}

Economic Development, Technological Change and Growth, Measurement of Economic Growth, Macroeconomic Analysis of Economic Development

\section{ECONOMIC GROWTH}

The World Bank describes economic growth as quantitative change or expansion in a country's economy [1]. Still, economic growth is conventionally measured as the percentage increase in gross domestic product (GDP) or gross national product (GNP)during one year.

In his original work, Adam Smith [2] points out that increased specialization of labour and capital accumulation will lead to economic growth by means of "wealth of nations. "He also defines the growth process as endogenous and has put particular emphasis on the impact of capital accumulation. Much later, Harrod [3] and Domar [4] implied that economic growth depends on policies to increase investment- through increasing savings- and using that investment more efficiently through technological advances.

In 1956, Solow-Swan [5] extended the Harrod-Domar model to include a new term known as "productivity growth". "The model implies that: a) increasing capital relative to labour creates economic growth; b) poor countries with less capital per person will grow faster- for the reason that each investment in capital will produce a higher return compared to rich countries with sample capital; c) because there is a diminishing returns to capital, in the long-term, economies will reach a point at which no new increase in capital will create economic growth and this point is called "steady state".

However, economists observed that if entrepreneurship is not activated capital accumulation and division of labour cannot afford to generate business cycles. From this perspective, Schumpeter [6] views entrepreneurship as having a major influence on a 
society's rate of technological progress and thus economic growth. Schumpeter's great achievement is strengthening the role of innovators and innovations in the economy [7]. Thereby, entrepreneurship forces "creative destruction" across markets and industries, simultaneously creating new products and business dynamics. Later on in his papers, Kaldor [8] supported the Schumpeter approach and implied that a satisfactory growth theory cannot be constructed without a business cycle theory.

Another alternative approach to the accumulation of factors which ensure long-term (or sustained) growth is the introduction of technical progress. In his article, Romer [9] emphasized that economic growth is an endogenous outcome of an economic system, not the result of forces imposed from the outside. According to Romer, the focus is "on the behaviour of the economy as a whole" [10]. However, according to Barro and Martin [11] the long-term growth rate also depends on governmental actions, such as taxation, maintenance of law and order, provision of infrastructure services, protection of intellectual property rights, and regulations of international trade, financial markets, and other aspects of the economy such as institutions.

Consequently, when describing economic growth for transition economies, another well known approach for measuring GDP is Total Factor Productivity (TFP). In his landmark article, Solow [5] underlines that long-term growth in income per capita in an economy with an aggregate neoclassical production function must be driven by growth in TFP. Later on, Klenow and Rodriguez-Clare [12] and Hall and Jones [13] confirmed that majority of the gap in income per capita between rich and poor countries is associated with large cross-country differences in TFP [14]. Recognizing that a large portion of TFP growth is caused by endogenous innovation decisions has significant implications for business cycles and this is important when focusing on transition economies.

Regardless of economic changes and social challenges, financial crises have encouraged countries to develop various approaches and tools in order to foster their economic growth and development. Transition countries in particular worked on building up their institutional and human capacities, and developing efficient tools and methods in order to reallocate their economic resources.

Consequently, from an economic perspective, Macedonia has liberalized and opened its economy and has implemented a significant number of difficult and complex market-oriented structural reforms. Nevertheless, in order to move toward a well-functioning market economy and achieve successful transition reforms, the government of Macedonia has followed the path of restructuring and stabilization of the economy and adapting key reforms for the transition [15].

\section{Economic Growth and Characteristics of Transition in Macedonia}

In 1989, a convergence of economic views was developed around the so-called "Washington consensus" [16]. However, the transition countries that systematized their economies based on Washington Consensus experienced failure [17].

According to Ofer [18], the pattern of economic growth in socialist countries was based on extensive growth, that is, it favoured factor accumulation instead of technological and institutional changes. During this period of time, technology was lagging in transition economies, but with the free flow of information and Western assistance, it was expected that it could be overcome. However, Campos and Coricelli [19] emphasized that: a) the absence of capital markets and restrictions to capital mobility generated a regime of "investment hunger"; b) industrial structure was based on heavy industry not on light industry; and services were considered as "unproductive" items of the growth; c) there was no unemployment under socialism, but constant excess demand 
for labour existed. Moreover, the absence of innovations in conjunction with the lack of technological progress resulted in no entry of new firms and no competition [20].

For these reasons by the end of the nineties, the Washington Consensus was extended to the so-called "second generation policies" and directed measures towards good governance-stretching from reforms of bureaucracy to labour market reforms, anti-corruption measures, social safety nets and poverty reduction programmes [21].

Considerably, the transition process itself was a part of the "creative destruction" building up a market system and simultaneously destroying the legacies of at least a halfcentury of planned economy [22].

Stabilization effort. The main approach of the Macedonian economy during the transition period, based on the Washington Consensus criteria, was to achieve stabilization in the market, to stabilize the monetary policy, to regulate the public finances and to reform the civil society. For these reasons, in 1995, the government and National Bank of Republic of Macedonia (NBRM) established a stabilization program in order to decrease inflation, reduce public debt and stabilize the volatile performance of the economy. According to Fiti [23] within this context, two complex groups of issues were of particular importance for overcoming the economic stagnation and alleviating unemployment in the Macedonian economy: "the restructuring of the real sector" and "the increase in physical and human capital investment", whereas, Petreski [24] emphasizes that analysis of actual and potential sources of growth in Macedonia have to be clearly prescribed and analysed.

In the overall transition period, economic growth was sluggish and volatile. Hence, recorded growth in the period of 2003-2009 placed Macedonia among the slowest growing economies in Southeast Europe [22]. The persistence of low rates of the real growth accompanied by significant fluctuations raises concerns about the real capacity of the overall economy to generate growth.

However, the civil conflict in 2001 disrupted a brief period of positive economic momentum. Although direct damage from the conflict was limited, investment activity markedly dropped; defence-related expenditures pushed the budget and increased current account deficits. Thus, effects of the conflict were clearly felt in 2002 as investment and export growth remained sluggish while budget and current account deficits remained high[25]. Further, political and social restructuring policies were damaged, whereas institutional and structural improvement lagged behind and unemployment significantly increased.

The source of GDP growth. The large contribution from TFP is common during the initial period of post-communist transition, where TFP growth is a result of elimination of inefficiencies of the former economic regime. Recent empirical analyses of IMF [26] emphasize that capital formation and employment have become more significant determinants of the growth rate in Macedonia. IMF analysis explains that growth in Macedonia is mainly driven by total factor productivity (TFP). According these data, TFP accounted for almost two-thirds of output growth for the periods 1996-2000 and 2001-2008, while the contributions from labour and capital have been low, explaining around one-third of the growth rate [27].

The growth of the TFP during the transition period can be mainly attributed to the reallocation of labour and capital resources during the establishment of a market economy, a source that is already fully exploited [28] (Figure 1). 


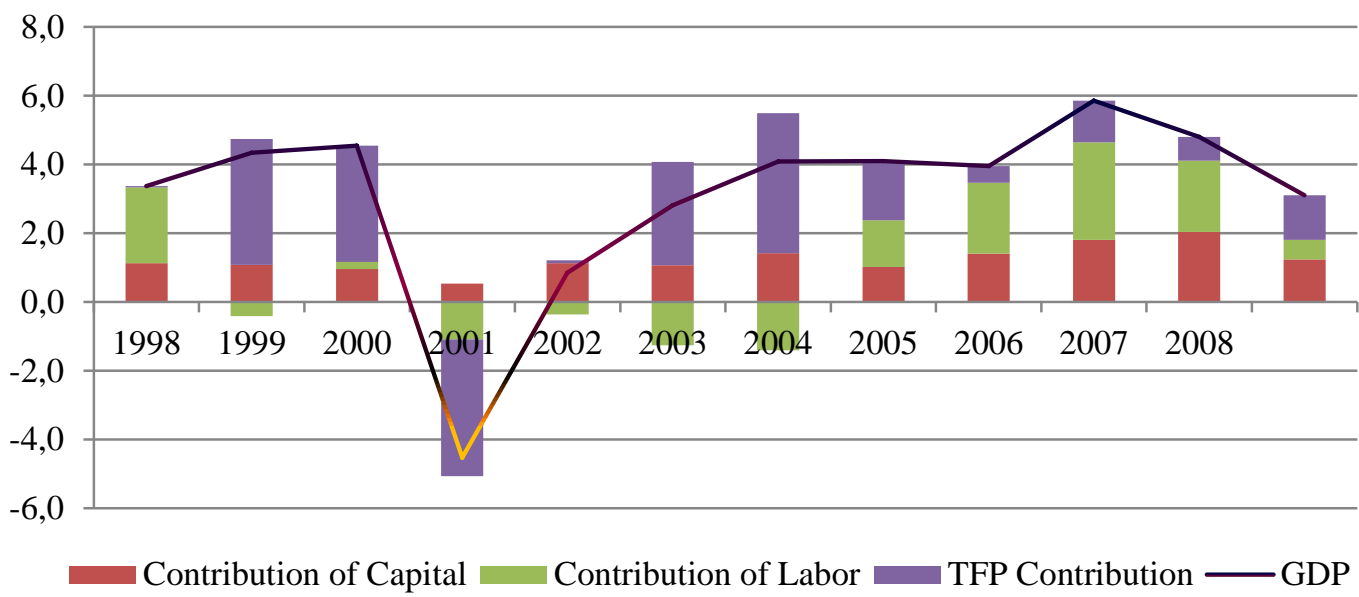

Figure 1.Contribution and share of the production factors and TFP to growth in Macedonia $(1998-2008)$

Source: The World Bank staff calculations

However, in the standard growth accounting framework, decomposing GDP growth into growth of factor inputs and residuals, reveals that in Macedonia, the total factor productivity had the largest impact on overall growth with $42 \%$ over the period 1998-2008 (see Table 1).

Table 1.Contribution and share of the production factors and the TFP to growth in Macedonia

\begin{tabular}{c|ccc}
\hline Growth of GDP & Capital & Labour & TFP \\
\hline $3.1 \%$ & $1.2 \%$ & $0.6 \%$ & $1.3 \%$ \\
& $(38.71 \%)$ & $(19.35 \%)$ & $(41.94 \%)$ \\
\hline
\end{tabular}

Source: The World Bank staff and author's own calculations

Consequently, Macedonian economy would not grow rapidly without large initial infusions of capital and labour. In order to increase the private and public saving rates, to generate business cycles that positively affect economic growth; and dynamic mechanism that increases social welfare and social capital accumulation, Macedonia needs some other "engine of growth"-in addition to factor accumulation.

\section{FROM EXOGENOUS TO ENDOGENOUS ECONOMIC GROWTH}

For deeper investigation of the potential sources of economic growth in Macedonia as post-transition economy, an endogenous economic growth approach is tested. The purpose of this analysis is to provide an exploratory analysis of the gross capital formation, gross domestic savings, research and development (R\&D), health expenditure, population growth and institutional improvement -economic growth nexus.

According to Osipian [29] the basic specification of Mankiw-Romer-Weil [30] can be modified to estimate GDP growth rates over a certain period (1998-2008), including a wide range of variables as determinants of productive economic growth. The assumed regression equation is the following:

$$
Y_{i t}=\beta_{0}+\beta_{1} I_{i t}+\beta_{2} R_{i t}+\beta_{3} S_{i t}+\beta_{4} H_{i t}+\beta_{5} N_{i t}+\beta_{6} G O V_{i t}+\epsilon_{i t}
$$


$Y_{i t}$ refers to the growth rate during each period, $I_{i t}$ is the rate of gross capital formation (equal to savings) as a percentage of GDP, $R_{i t}$ is rate of R\&D (as GDP percentage) for each period, $\mathrm{S}_{\mathrm{it}}$ is the rate of gross domestic savings (as GDP percentage), $H_{i t}$ is the rate of health expenditure (as a GDP percentage), $N_{i t}$ is the rate of population growth and $G O V_{i t}$ is institutional improvement indicator [31].

\section{Empirical Results}

This section details the findings from the estimation of the equation. The approach is estimated using Ordinary Least Squares (OLS) for the growth equation. First, $\mathrm{R}^{2}$ of the model is interpreted. It is expected that as the value of adjusted $\mathrm{R}^{2}$ increases the model is better explained. However, it would be a mistake if analyses are interpreted based on

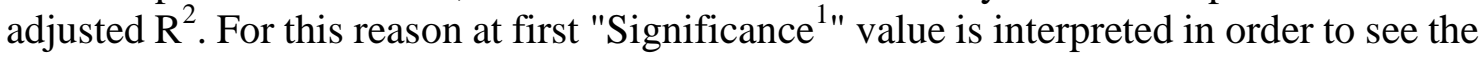
goodness of fit of the model. If the value in "Sig." is less than 0.05 , then it is assumed that the estimate in column " $\mathrm{B}$ " can be asserted as true with a $95 \%$ level of confidence. If this value is more than 0.1 then the coefficient estimate is not reliable because it has "too" much dispersion/variance.

On the basis of the obtained economic growth, correlation analysis is used for investigating the relationship between economic growth and its determinants. Next, independent-samples T-test is used for finding of the mean differences within economic growth factors.

Table 2 presents regression results - based on separate regression analysis - of each variable explained in the research. Regarding "Sig." value of predictor variables investments, health expenditure, and institutional improvement appears to be statistically significant. However, the effect of R\&D, gross domestic savings and population mostly remains weak and statistically insignificant for the Macedonian economy.

Table 2. Results of stepwise analysis of the variables

\begin{tabular}{|c|c|c|c|c|}
\hline \multirow[b]{2}{*}{ Predictors } & \multicolumn{4}{|c|}{ GDP growth annual '98-'08 } \\
\hline & Stand. Beta & Sig.of Beta & $\begin{array}{c}\text { Sig. } \\
\text { (ANOVA) }\end{array}$ & $\begin{array}{c}\text { Adj. } \\
\text { R square }\end{array}$ \\
\hline Investments & 0.602 & 0.102 & 0.5 & 0.292 \\
\hline$R \& D$ & -0.333 & 0.333 & 0.333 & 0.004 \\
\hline $\begin{array}{l}\text { Gross Domestic } \\
\text { Savings }\end{array}$ & 0.049 & 0.887 & 0.887 & -0.108 \\
\hline Population-POP & -0.411 & 0.209 & 0.209 & 0.077 \\
\hline $\begin{array}{l}\text { Health } \\
\text { Expenditure }\end{array}$ & -0.188 & 0.58 & 0.58 & -0.072 \\
\hline GOV & 0.717 & 0.013 & 0.013 & 0.209 \\
\hline
\end{tabular}

Source: Authors' calculations

Estimation results show that due to the small sample size of the data, separate regression of each variable is weak in terms of explaining the impact of independent variables to GDP growth.

For these reasons, Table 3 presents regression results with predicted variables of growth calculating their impact on GDP. In this approach, the goodness of fit of the regression model is significant (ANOVA Sig. is 0.007$)^{2}$ and it implies that we can accept the equation. Whereas, if "Sig." less than 0.05 then it is assumed that the estimate in

\footnotetext{
${ }^{1}$ Within the text it would be referred as Sig.

2 Typically, if "Significance" is greater than 0.05 , it is concluded that our model could not fit the data.
} 
standardized coefficients column "B" could be asserted as true with a 95\% level of confidence. Regression analysis is significant with $\mathrm{R}^{2}=0.988$ and adjusted $\mathrm{R}^{2}=0.961$.

Table 3. Results of the full regression analysis (all variables included)

\begin{tabular}{|c|c|c|c|c|c|}
\hline \multirow[t]{2}{*}{ Predictors } & \multicolumn{2}{|c|}{$\begin{array}{l}\text { Non-standardized } \\
\text { Coefficients }\end{array}$} & \multirow{2}{*}{$\begin{array}{c}\begin{array}{c}\text { Standardized } \\
\text { Coefficients }\end{array} \\
\text { Beta }\end{array}$} & \multirow[t]{2}{*}{ t-stat } & \multirow[t]{2}{*}{ Sig. } \\
\hline & Stand. Beta & Std. Error & & & \\
\hline (Constant) & -13.537 & 4.169 & & -3.247 & 0.048 \\
\hline INV & 0.751 & 0.151 & 0.592 & 4.966 & 0.016 \\
\hline $\begin{array}{l}\text { Gross Domestic } \\
\text { Savings }\end{array}$ & 0.789 & 0.105 & 0.776 & 7.536 & 0.005 \\
\hline $\mathrm{R} \& \mathrm{D}$ & -4.210 & 3.958 & -0.239 & -1.064 & 0.366 \\
\hline Health & 0.372 & 0.184 & 0.234 & 2.017 & 0.137 \\
\hline Population-POP & -1.482 & 0.351 & -1.061 & -4.221 & 0.024 \\
\hline GOV & -8.215 & 5.054 & -0.562 & -1.625 & 0.203 \\
\hline
\end{tabular}

Source: Authors' calculations on the basis of assumptions

The results of the coefficient of the investment variable are positive and statistically significant and this shows that it has positive impact on GDP growth in Macedonia. The R\&D standardized beta coefficient is negative (-) 0.239 and it is statistically insignificant. Thus, it is observed that data of R\&D for Macedonia is not continuous and remains poor. Consequently, it could be concluded that regarding long-term intensive growth, the impact of $R \& D$ on economic growth is not observable yet.

The gross domestic savings coefficient is positive (0.776) and statistically significant. However, the domestic saving rate of the economy remains poor; although it is seen as an indicator of generating investments.

As regards health expenditure, the explanatory coefficient is positive 0.234 but statistically insignificant (with sig.=0.137) in the case of Macedonia it could not be explained due to poor data availability. However it could be concluded that, as a social determinant, it is not improved.

Furthermore, the institutional coefficient remains weak with (-) 0.562 and statistically insignificant. It could be concluded that the transition itself has not improved its legacies. It is observed that negative population growth is the result of slowed economic performance. Thus, the population growth coefficient is negative and statistically significant.

Consequently, from the viewpoint of growth, due to poor and non-sustainable data availability, it could be concluded that the transition itself had a negative impact on Macedonia's market system. Macedonia needs fast and dynamic improvement at all levels in order to promote economic growth and stability.

\section{CONCLUSIONS}

Macedonia's record of growth and macroeconomic stabilization has been marred by a lack of comparable progress in structural and institutional reforms. Poorly functioning institutions-restrictive labour market regulations, inefficient state institutions and dysfunctional courts- have directly undermined business activity and kept per capita FDI low, even by regional standards.

In circumstances of a deteriorated business climate and declining economic effects, the Macedonian economy is still experiencing serious shortcomings related to functioning of its real economic sector, especially industrial. The decade of privatization 
and transition could be declared as one of the reasons behind the decreasing trends for GDP per capita and creates the inability of the economy to generate a net physical and human capital accumulation and persistent social cohesion.

Synthesis of the research results offers several implications and suggestions for the relationship between economic growth and its determinants. It can be observed that clear positive factors behind growth related factors would be more significant with increased human capital and institutional improvement. However, these factors, more specifically institutional indicators, are more or less under the control of political authorities. Thus, in order to fulfil these legitimate expectations, institutional development should go hand-in-hand with the development of legal and social systems. Also, supporting equality and expertise would generate positive externalities on institutional and economic level.

Furthermore, political activity is higher in the society and educated persons (due to employment policy based on political membership) in Macedonia, so investment in the educational system might help to strengthen the mechanisms which lead from political activity to higher pressure on public institutions, thus increasing their effectiveness and trustworthiness. The resulting increase in the quality of governance should, in turn, lead to a more stable environment for investments in particular and economic growth in general.

In conclusion, generational change might be one of the possibilities to overcome the negative influence of the socialist past on the various levels of human and social capital.

\section{NOMENCLATURE}

$\begin{array}{ll}\text { GDP } & \text { Gross Domestic Product } \\ \text { GNP } & \text { Gross National Product } \\ \text { IMF } & \text { International Monetary Fund } \\ \text { NBRM } & \text { National Bank of the Republic of Macedonia } \\ \text { OLS } & \text { Ordinary Least Squares } \\ \text { R\&D } & \text { Research and Development } \\ \text { Sig. } & \text { Significance } \\ \text { TFP } & \text { Total Factor Productivity }\end{array}$

\section{REFERENCES}

1. World Bank, Beyond Economic Growth. Washington D.C.: The World Bank, 2004.

2. Smith, A., An Inquiry the Nature and Cases of the Wealth of Nations, 1776, Retrieved from Library of Economics and Liberty, 2008. http://www.econlib.org/library/Smith/smWN1.html\#B.I, Ch.I Of the Division of Labor

3. Harrod, R. F., An Essay in Dynamic Theory,Economic Journal, 49 (193), pp.14-33, 1939.

4. Domar, E., Capital Expansion, Rate of Growth, and Employment, Econometrica, 14, pp.137-147, 1946., http://dx.doi.org/10.2307/1905364

5. Solow, R., A Contribution to Theory of Economic Growth,The Quarterly Journal of Economics, Vol. 70 (1), pp.65-94, 1956., http://dx.doi.org/10.2307/1884513

6. Schumpeter, J., Business Cycles. A Theoretical, Historical and Statistical Analysis of Capitalist Process. New York: McGraw-Hill,1939.

7. Schumpeter, J., The Theory of Economic Development. Leipzig, Cambridge,: Massachusetts: Harvard University Press, 1934.

8. Kaldor, N., The Relation of Economic Growth and Cyclical Fluctuation. Economic Journal, 64 (253), pp.53-71, 1954., http://dx.doi.org/10.2307/2227090 
9. Romer, P.M., The Origins of Endogenous Growth. The Journal of Economic Perspectives, 8 (1), pp.3-22, 1994., http://dx.doi.org/10.1257/jep.8.1.3

10. Ibid.

11. Barro, R. J., and Martin, X. S.-i., Economic Growth (2nd ed.), Cambridge: MIT Press, 2004.

12. Klenow, P., and Rodriguez-Clare, A.,The Neoclassical Revival in Growth Economics: Has It Gone Too Far? Cambridge,Massachusetts: NBER Macroeconomics Annual, MIT Press, 1997.

13. Hall, R., and Jones, C.,The Productivity of Nation, Cambridge, Massachusetts: NBER Working Paper No. 5812, 1996.

14. Comin, D. and Gertler, M., Medium Term Business Cycles,American Economic Review, 96 (3), pp.523-551, 2006., http://dx.doi.org/10.1257/aer.96.3.523

15. World Bank,FYR Macedonia Country Economic Memorandum:Enhancing Growth.Washington D.C.: The World Bank,1998.

16. Williamson, J.,What Should the World Bank Think About the Washington Consensus?Retrieved from www.iie.com (Peterson Institute for International Economics),

2008. http://www.iie.com/publications/papers/paper.cfm?ResearchID=351

17. Rodrik, D., Goodbye Washington Consensus, Hello Washington Confusion? Journal of Economic Literature, XLIV, pp.973-987, 2006., http://dx.doi.org/10.1257/jel.44.4.973

18. Ofer, G., Soviet Economic Growth: 1928-85. Journal of Economic Literature , pp.767-1833, 1987.

19. Campos, N. F., and Coricelli, F.,Growth in Transition: What We know, What We Don't, and What We Should.Washington D.C.: William Davidson Institute Working Paper 470, February 2002., Retrieved from http://wdi.umich.edu/files/publications/workingpapers/wp470.pdf

20. Ofer, G., Soviet Economic Growth: 1928-85. Journal of Economic Literature , pp.767-1833, 1987.

21. Rodrik, D.,Is There a New Washington Consensus?, 2008. Retrieved January 2010, from http://www.project-syndicate.org/commentary/rodrik20

22. Michalopoulos, C.,The Western Balkans in World Trade.Washington D.C.: The World Bank, 2003.

23. Fiti, T., Macroeconomic Stability and Growth. In Open Challenges to the Macedonian Economy, Skopje: MANU, pp.23-48, 2004.

24. Petreski, G., Missing Growth-Is the Accelaration of Growth Possible. In Open Challenges to the Macedonian Economy, Skopje: MANU, pp.159-198,2004.

25. World Bank, Country Partnership Strategy for the Former Yugoslav Republic of Macedonia for the period 2007-2010,Washington D.C.: The World Bank,2007.

26. IMF,Former Yugoslav Republic of Macedonia: Selected Issues, Washington D.C.: IMF, 2009.

27. Ministry of Finance of Republic of Macedonia, M. o. (2007, December). Macroeconomic Policy 2008., Retrieved from Ministry of Finance: http://www.finance.gov.mk/files/u9/Makroekonomska_politika_2008.pdf

28. The World Bank data for capital, labor and TFP contribution to economic growth in Macedonia in the period of time 1998-2008. Data is calculated and provided by The World Bank staff in Macedonia.

29. Osipian, L. A.,The Impact of Human Capital on Economic Growth: A Case Study in Post-Soviet Ukraine, 1989-2009, New York: Palgrave Macmillan, 2009. 
30. Mankiw, N.G., Romer, D. And Weil, D.N., A contribution to the Empirics of the Economic Growth, The Quarterly Journal of Economics, Vol. 107, No.2, pp.407-437, May, 1992., (from p. 416 of the paper, the production function is $Y_{t}=K_{t}^{\alpha} H_{t}^{\beta}\left(A_{t} L_{t}\right)^{1-\alpha-\beta}(Y, K, H$, and $L$ represent total output, physical capital stock, human capital stock, and labour, respectively)

31. The data sources include World Bank Indicators, World Development Database and Governance Indicators that are calculated and measured by World Bank staff for Macedonia; it covers the period from 1998 to 2008. 